\author{
Lechosław Lameński \\ (i) https://orcid.org/0000-0002-2691-1297 \\ Professor Emeritus at the Institute of Arts Studies, the John Paul II Catholic \\ University of Lublin \\ lamenski@wp.pl
}

\title{
THE ARTIST AND HIS CITY. NEW YORK IN THE WORKS OF TADEUSZ MYSŁOWSKI
}

\begin{abstract}
Tadeusz Mysłowski, born in 1943 in the village of Piotrków near Lublin, a graduate of the Academy of Fine Arts in Krakow, left Poland in 1969. His first destination was Paris and then, in 1970, the United States. From that moment on, he has been living and working in New York, a city that has become an inexhaustible source of inspiration for him. Fascinated by the urban layout of Manhattan, its astounding network of streets, he abandoned traditional painting techniques in favour of a black-and-white series of drawings, prints, collages, photomontages and installations, created in the spirit of geometric abstraction and Constructivism, the art trends that were particularly dear to him. His works display transformed portions of the architectural structures of this extraordinary city with which the artist conducts a never-ending formal discourse. Mysłowski has always been supported by his wife Irena Hochman, an art historian by education, owner of a notable art gallery and an important figure in the American art market. Tadeusz and Irena share not only a passionate relationship, but also a great collector's passion, which has resulted in the creation of an interesting collection of works by Polish, European and American artists who were primarily active in the 20th century. These are exclusively works on paper, mainly prints made using all possible graphic techniques. In 2017, the couple donated a part of the collection to the then Lublin Museum (now the National Museum in Lublin) and placed some of the artworks on a long-term loan.
\end{abstract}

Keywords: Tadeusz Mysłowski, Irena Hochman, New York, fascination, love, geometric abstraction, collection

"Tadeusz Mysłowski is an artist whose work explores the aspect of space in a special way, thus allowing the viewer to develop an interest in space in relation to his work. His life, which was marked by a trans-migratory journey 
between his hometown of Lublin and his new home in New York, results in the prevailing need to recognize and organize the contexts of place. The artist's consistent use of a motif which is created by the intersection of two perpendicular lines carries a powerful symbolic load; it is also found within grid phenomena or in architectural structures and sets the direction of activities, marking the spaces already penetrated by him". ${ }^{1}$

The quotation above constitutes the opening lines of a book by Krystyna Rybicka, devoted entirely to Tadeusz Mysłowski and his art. The artist, who was born in 1943 in the small village of Piotrków near Lublin, has been living and working successfully in New York since 1970, i.e. for over half a century. However, he has stayed in touch with his home country and his works have been regularly displayed (forming a part of individual and collective exhibitions) in the most notable Polish museums and galleries, especially after 1989. In 2009, his monumental diptych He and She, Makeover (size of each part: $205.8 \times 75.0 \mathrm{~cm}$ ), made using the woodcut technique, was awarded one of the five main awards by the jury of the 19th International Print Triennial in Krakow, which undoubtedly contributed to a growing interest in his art. It is little wonder that native art critics, including those from Lublin (e.g. Krystyna Rybicka, the author of the most extensive and, at the same time, the most important publication about the artist to date), are writing about him more and more often. In her fascinating book, she conducted an in-depth analysis of Tadeusz Mysłowski's art, emphasizing its spatial aspect in the context of the most interesting achievements of avant-garde art in the 20th century, especially artworks created in its first two decades including the period of the First World War. It is apt that the author noted that the roots of Mysłowski's artistic search may be found in all noteworthy trends in the field of geometric abstraction which was emerging at that time. Although we have already arrived at the beginning of the third decade of the 21st century, Tadeusz Mysłowski's reference to over a hundred years of tradition, an obvious historical discourse, has not led his rich and exceptionally formally coherent art to become the work of an eclectic secondary artist, as it might seem at first glance. Owing to his genuine talent, great sensitivity, exceptional diligence, as well as his extensive theoretical

1 Krystyna Rybicka, Twórczość Tadeusza Mysłowskiego a kreacje przestrzeni w sztuce XX wieku, ed. Muzeum Lubelskie, Lublin 2018, p. 7. The book is a printed version of the doctoral dissertation of the author, defended at the then Institute of Art History of the Catholic University of Lublin (currently the Institute of Arts Studies) in 2017, under the supervision of prof. dr hab. Lechosław Lameński. The reviewers were: prof. dr hab. Grzegorz Sztabiński and dr hab. Dorota Folga-Januszewska. Since all the information about the artist's life and work provided in this article has been taken from this very well documented book, only short quotes from other researchers' articles have been annotated in order to avoid unnecessary repetition. 
knowledge and necessary practical experience gained over decades, he is able to add to his very diverse projects a unique element of freshness and originality, because he is equally a painting artist, graphic artist and photographer, as well as creator of multimedia installations. As a result, his compositions boldly use formal solutions proposed by the fathers of geometric abstraction and conduct a constant dialogue with them, showing curious viewers of exhibition halls in his home country and abroad that simple geometric forms present in contemporary art have not gone out of date but can still inspire, providing the basis for subsequent and completely new artistic proposals.

It all began when Tadeusz Mysłowski left for Paris in the autumn of 1969 and then, in 1970, to the United States. The USA became his second homeland, while New York, where he lived, has been an inexhaustible and fascinating source of inspiration for the artist up to the present time, and the starting point for a multi-faceted discourse. It seems that there were at least two reasons for the artist to go abroad. The first reason was that this graduate of the Academy of Fine Arts in Krakow, a gifted student of e.g. Wacław Taranczewski, one of the last Polish colourists, felt that there was simply "not enough space for him" in the historic city of Krakow which was attached to its great traditions, as Krystyna Rybicka aptly noted. Tadeusz Mysłowski, who was educated mainly in the spirit of Colourism omnipresent in Polish painting art from the early 1930s, was already far more interested in moderately avant-garde art, especially Cubism. Due to his private acquaintances and frequent visits to Łódź, mainly to the local Art Museum, he became impressed with the works of Władysław Strzemiński, Katarzyna Kobro and Henryk Stażewski. In 1967, as part of a cross-cultural academic exchange of students, he managed to visit the Art Institute in Kiev, where he was introduced for the first time to certain aspects of Neoplasticism and Suprematism. These art movements, together with their creators, Piet Mondrian and Kazimierz Malewicz, became deeply fixed in his memory. He was a young and rebellious artist who did not want to paint in the same way as his colleagues, and even less like the academic professors who had taught him, so he decided that "his new city, the place where he should be, is Paris". ${ }^{2}$

Whether it was really a good choice or not is difficult to say. Nevertheless, 26-year-old Mysłowski began his stay in Paris with a debut exhibition at Galerie Lambert run by Zofia and Kazimierz Romanowicz at Île Saint-Louis in the very heart of city. And it was an absolutely successful debut, which was noted simultaneously not only by Polish-language émigré press ("Tygodnik Polski") and local Lublin press ("Kurier Lubelski") but, above all, by French critics

2 Ibid., p. 23. 
who would not usually be too eager to positively assess the achievements of foreigners. Favourable reviews were published in "Internationale", "Opus", "Le Figaro", "Le Nouveau Journal" and "Galerie des Arts". The future of the young Lublin artist seemed to be bright. Unfortunately, despite his strenuous efforts, the French authorities did not extend his residence visa. So, he was left with a dilemma: either return to Krakow, the place where he had studied, which had become too ossified in his opinion, or go to the United States, a place open to any experiment, in order to join Irena Hochman, the love of his life. This was the second and perhaps most important reason for Mysłowski's voluntary emigration. Tadeusz had met Irena a few years earlier (in 1966) in Kazimierz Dolny, when she was a medical student in Krakow. They had fallen in love with each other. Unfortunately, as a result of a nationwide anti-Semitism crisis, which culminated in the events of March 1968, Irena had to leave with her parents via Vienna to travel to New York. As soon as she arrived in the US, she changed her field of study and completed a comprehensive course of studies in the field of art history because she had always found it interesting. Due to her great determination, diligence and established professional contacts, in 1975, together with the famous publisher Bernard Jacobson, she opened her first art gallery: Jacobson \& Hochman Gallery. Today, after more than 40 years of her successful presence in the difficult and demanding American art market, Irena Hochman is not only a highly esteemed and respected gallery owner, but also an outstanding expert in contemporary art. She collaborates with a number of top local and foreign artists, regarding "extensive cooperation with institutions promoting contemporary art in Japan and providing advisory services concer-

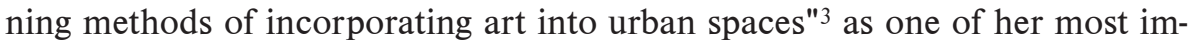
portant successes.

Thus, a fascination with art and passionate love connected Tadeusz with Irena, creating a wonderful complementary duo who found it impossible to live without New York. In fact, from the first moments they spent in The City That Never Sleeps, they both succumbed to its magic and power of expression. Their lives and work were dominated forever afterwards by the continuous discourse between the centuries-old tradition they had brought from Europe, daily reality steeped in history and what the insane present day of the unconstrained New World offered them. Tadeusz Mysłowski, who had been brought up in a completely different reality, was fascinated from first sight by the grandeur of Manhattan's urban layout, its clarity and logic. This layout was consistently developed over a period of three years (from 1808 to 1811) by John Randel Jr. (1787-1865). He was a visionary surveyor, who, in opposition to everybody and

3 Ibid., p. 27. 
everything, transformed the picturesquely hilly island with a diverse topography into a completely flat space, dividing the whole area with an abstract grid into 228 equal quarters designated for development. This spatial layout still applies today. New, more and more interesting taller buildings are being erected within it, with their outlines dominated by geometric forms, having close ties with Mysłowski's art and especially with his synthetic thinking about art and space in which it exists and functions. In 1980, in an interview with Ronny $\mathrm{H}$. Cohen, the artist frankly admitted: "I first saw New York from a plane, and believe me, this view has completely changed my visual perception of reality. [...] New York is very simple and ordered, and its structure is to some extent based on a grid of intersecting lines. I realized immediately that I needed to know how New York was structured and as soon as I moved here, I started to collect all of the available information about the city, mainly from sources such as maps and photos taken from a bird's eye view, etc."4

It is little wonder that from the very beginning of his stay in the United States, the artist from Lublin always carried his camera around. It is an indispensable tool of field work and the means by which he captures images of New York, especially of Manhattan buildings with their unique beauty, and tries to recreate, interpret and discover them for the needs of his own art. However, these images are not ordinary postcard photographs taken at the right distance using a wide lens, on which one may recognize the most interesting or characteristic parts of the city, with the façades of architectural icons shown in full, from street level to the roof, with all the important details. These are certainly draft photographs, but with a clear artistic overtone. They formed the basis for the creation of many future drawings, graphic and painting compositions, as well as photomontages and collages which were completed as part of the entire black-and-white series of works which dominated the artist's portfolio over the following decades.

When photographing the buildings of individual quarters of Manhattan, Mysłowski focuses his attention on specific parts of geometric blocks, most particularly on the relationship between them, formed by sharp contrast between light and shadow on their completely flat and smooth surfaces (façades), clear texture resulting from the use of contrasting materials and threedimensional construction. The artist attempts to capture their unsophisticated beauty, originality and regularity of the simplest forms, usually unnoticed by the busy inhabitants of New York, from different angles. For this purpose, he

4 Tadeusz Myslowski: Interview by Ronny H. Cohen, „The Print Collectors Newsletter” 1980, no. 2, p. 44, quoted after: Grzegorz Sztabiński, Działania artystyczne Tadeusza Mystowskiego i ich konteksty, [in:] Idem, Dlaczego geometria? Problemy wspótczesnej sztuki geometrycznej, Ed. Uniwersytet Łódzki, Łódź 2004, pp. 161-162. 
uses complicated perspective shortcuts, which makes them unique examples of monumental architectural sculptures on a scale that is difficult to embrace. As a result, the beating heart of New York - Manhattan - is a vibrant unique organism for Mysłowski, providing a constant source of inspiration for his art. It must be stated that without contact with this place, his work would probably be completely different and certainly much more limited.

Besides Piet Mondrian's neoplastic painting compositions, Mysłowski is fascinated by the simplest sign of the cross, resulting from the intersection of two lines, two plain-coloured surfaces at a right angle. He builds his own world of visual signs on this basis. It is a world that is intriguing, full of surprising formal solutions and unexplored secrets. It turns out, quite surprisingly, that the modest motif of the cross creates almost unlimited possibilities which may be realized on a two-dimensional flat surface of canvas, paper or photographic print, as well as be transferred into the three-dimensional space of wooden cubes, ChairThrones and even Endless Columns, which are close to the style of abstract "arkhitektons" by Kazimierz Malewicz.

In all of his artistic activities, Mysłowski is painfully consistent. Especially in the case of willingly created numerous photomontages, he aptly integrates the ordered grid of Manhattan streets into sequences of figures and geometric forms that interest him. Their starting point was the aforementioned cross, creating a completely new reality which is as interesting as the existing one. In this way, a dichotomous space is created, in which the geometricism of his compositions, their numerous variants and mutations result in this outwardly similar motif to create a completely new form, as fascinating as the previous one, perfectly harmonizing with the world expressed in Manhattan's architecture from the beginning of the 19th century.

The experience he gained during his short stay in Paris, years of study at the Academy of Fine Arts in Krakow, but especially his contact with avantgarde art in galleries, museums and artists' studios, both at home and abroad, later brought tangible results in the US. Tadeusz Mysłowski definitely rejected colour and ceased to be the "classic" painting artist that he was when he left Poland, transforming himself into an art experimenter fascinated by black-andwhite graphics and photography, which resulted in new, extremely interesting expressive possibilities. In 1971, the artist stated: "My works are a continuation of the art of constructivism using new tools and materials, moving away from a structure based on metaphysics to a geometrical systematic and logical structure". ${ }^{5}$ In Mysłowski's words, "The camera allowed for the analytical systemati-

5 See: Lechosław Lameński, Czarno-biały zapis emocji wedtug Tadeusza Mystowskiego, „Akcent” 2009, vol. 30, no. 3 (117), p. 174. 
zation of my work. As a research tool, it established a special logic for me, which was derived from its mechanical/optical nature, allowing me to rearrange the available information in a way that avoided the overriding visual narrative". ${ }^{6}$

As a result of his fascination with New York and the desire to face its extraordinary reality, New York Faces project was created in 1974. It consisted of computer portraits of people living in different parts of the city. Mysłowski, satisfied with the artistic effect achieved, continued with the idea in the years 1976-1979, setting up a camera at Times Square - one of the most recognizable icons of New York, visited by large crowds of both city residents and tourists, regardless of the time of year and day. The camera was coupled with a computer and a printer, and it photographed as many as 3,000 random passers-by [sic!]. In this way, Mysłowski achieved a multiplied effect of an authentic recording of emotions, the capturing of a fleeting moment, a unique "reality" without any outside interference.

Most importantly, however, in 1974 he completed a series of twenty graphic prints bearing the common title: The Avenue of the Americas (the name of one of the streets in Manhattan). These works are the quintessence of the city, its structure and high-rise buildings at their most interesting, in the eyes of the artist who arrived from Europe. With sophisticated ease and perceptible intuition, Tadeusz Mysłowski brings the regular grid of Manhattan streets with office buildings, corporations and banks located next to them into twodimensional iconic graphic signs which, when copied and juxtaposed in new layouts, perfectly reflect their rhythm and character. Probably for the first time in the work of this Polish artist, pure geometric abstraction was replaced by an organic construction which would become, from then on, the hallmark of his subsequent compositions.

The Avenue of the Americas series, which received an award at the 5th International Print Biennale in Krakow in 1974, was enthusiastically received by Polish art critics, including Grzegorz Sztabiński who was first to take note of the talented graduate of the Academy of Fine Arts in Krakow. This philosopher, theoretician and art historian, being a painting artist and installation creator at the same time, noted that the artist from Lublin, who he became friends with shortly thereafter, used an interesting photographic technique when completing the series. Namely, he divided the initial "realization into parts of different sizes, enlarging some of them and thereby bringing out multiple, previously elusive aspects. He emphasized the collision of vertical and horizontal lines, the ambiguity of the relationship between the background and the figure (whether the black shape appears on a white background or vice versa), the line and

6 Ibid., pp. 174-175. 
blot (where we divide the original image into small fragments, the line begins to act as a blot), etc. The result was a long series of works created using various techniques (drawing, photography, photocopying)". ${ }^{7}$

"It showed, as we shall learn in the next paragraph, artistic conduct typical of Mysłowski and allowed for the capture of certain features that distinguished him from both constructivists and representatives of Minimal art. The art of both of these movements was nonrepresentational, but it was rather reduced to operating with simple forms typical of Euclidean geometry. In Mysłowski's realizations, as long as there was a subtle connection with nonrepresentational reality, a general suggestion of a connection with life is nevertheless unspecified and ambiguous " - as was rightly concluded by Sztabiński. ${ }^{8}$

From this point onwards, there was only a single step to be taken towards three-dimensional, truly spatial compositions, such as the series of sixty wooden Endless columns. This was displayed on many occasions (e.g. as part of the artist's individual exhibition at the National Museum in Warsaw in 1995), with geometrical cuboidal bodies on a square plan, composed of four identical completely smooth modules, only the last of which has some parts of the wood neatly cut at its finial. As a result, there is both a cross motif and a mysteriously empty space resembling a loggia or a narrow recess with an unspecified purpose. Positioned close to each other, in rhythmically repeating intervals, from a distance the columns give the impression of the highest skyscrapers erected in Lower Manhattan, at the southernmost part of this extraordinary island. The possibility to freely arrange each of the sixty Endless columns allowed the artist to create, as required, a different spatial composition with an undoubtedly architectural and urban message.

The same type of artistic expression also includes Mysłowski's visionary project which he called the ChairThrones. The series, completed by the Lublin artist in the years 2001-2010 in tribute to the great reformers of 20th-century art, initially consisted of five wooden objet d'art which could have strictly decorative functions at first glance. However, as it seems, according to the intention of their creator, the viewer looking at them was rather supposed to analyse relationships between their geometrized forms and the space which harmonizes with them. First, the following ChairThrones were created: Piet Mondrian's beam-woogie, Kazimierz Malewicz's square-cube, Władysław Strzemiński \& Katarzyna Kobro's negative-positive, Henryk Stażewski's module-square and Wacław Szpakowski's string-line. Over time, other works of art joined them: Rietveld and Truus Schroeder's redblueback, Henryk Berlewi's mechanized pattern, as well as Wassily Kandinsky's ChairThrone. The wordplay in the

7 G. Sztabiński, op. cit., p. 162.

8 Ibid. 
titles and, above all, the carefully modelled synthetic form, which is a metaphor for the works of the artists that Mysłowski was fascinated by, the effect of his acquired knowledge and in-depth reflection on their work, perfectly reflect the artistic personality of each of them. But I believe that the symbolic Chair-Throne is not only a successful attempt to establish a dialogue with the painting works of artists appreciated by the creator, but also an interesting sculptural and architectural concept to be implemented on a much larger scale. And so, Mysłowski wanted the ChairThrone of Malewicz to be placed near the Polonia Hotel in Warsaw, where the creator of Suprematism had stayed during his historic trip to Poland in 1927 and where his monographic exhibition took place at the end of March that year. Similarly, another (and the most personal) chair, Tadeusz Mysłowski's ChairThrone, a spatial composition with an exceptionally clear reference to the rhythmic divisions of Lower Manhattan area skyscraper elevations, may be placed in one of the alleys of the Old Town in Lublin.

Perhaps that is why Dorota Folga-Januszewska, an art historian, critic and museologist (curator of the artist's famous exhibition at the National Museum in Warsaw in 1995), recently recognized Tadeusz Mysłowski's work as Organic Constructivism which, in her opinion, is "an intellectual game of an artist with a provocative nature. It is the co-creation of forms which reflects the world order. This kind of art, which is conscious of a partnership with nature, is an extraordinarily historical (having its own record) road to the future. This horizon, however, is constantly shifting with us." ${ }^{\text {9 }}$

The enormous scale of Mysłowski's expressive abilities is also demonstrated by his publications, especially by the impressive volume accompanying the exhibition Tadeusz Mystowski studio/pracownia organized in 2018, at the hospitable premises of the then Lublin Museum (currently the National Museum in Lublin). ${ }^{10}$ This bulky 450-page book (a kind of a catalogue) is, in fact, a richly illustrated colourful story about the artist and his life in New York, realized in an unconventional layout, with a vivid record of the consistent emotional discourse he has had with this extraordinary city for fifty years now. It includes everything of consequence, from the initial fascination, through the first photos of the city's inhabitants, Manhattan architecture and interiors of galleries in New York and Poland with the artist's works exhibited there, reprints of reviews and articles about him (including those by Leszek Brogowski, Grzegorz Sztabiński,

9 Dorota Folga-Januszewska, Konstruktywizm organiczny Tadeusza Mysłowskiego, „Powidoki” 2019, vol. 1, no. 2, p. 29.

10 Then and now New York city fragments. Tadeusz Myslowski at the crossroads, publication accompanying the exhibition Tadeusz Mystowski studio/pracownia, Ed. Muzeum Lubelskie, Lublin 2018. 
Andrzej Turowski, Jan Stanisław Wojciechowski and Janusz Zagrodzki), and, importantly, a story about those close to him (especially Irena Hochman), his beloved Masters, as well as, understandably, the studio mentioned in the title (atelier). "The tribute to the Masters belongs to the artist's private ritual," wrote Szymon Bojko (1917-2014), a Polish art historian and critic with a particular interest in contemporary Polish artists working outside the country, mainly in the United States. "It is a domestic, intimate and secular sacred ritual. I noted this celebration - the critic wrote - when I visited the artist for the first time in Long Island City, on the other side of Manhattan. The studio, which was adapted from a garage and an ice factory [purchased by Irena and Tadeusz in 1979 - author's note], presents a cult object to a newcomer at the entrance - the imposing body of a car (white Jaguar 420, made in 1967). The artist reverently speaks of it as an icon of pure form. The living area is separated from the studio by a winding narrow staircase (with 67 steps). On the walls along the staircase, as in an art gallery, thoughtful faces stare at the guests from the photographs of the Masters. [...] It is worth quoting their names: Piet Mondrian, Kazimierz Malewicz, Katarzyna Kobro, Władysław Strzemiński, Ludwig Mies van der Rohe, Barnett Newman, László Moholy-Nagy, Friedrich Kiesler, Donald Judd, Robert Smithson, Isami Noguchi, Benoit Mandelbrot (the inventor of fractals), Michio Kaku and Julian Przyboś, a poet. The home panorama of the sign-images is complemented by the cult photograph of Albert Einstein sticking out his tongue - Signum temporis!". ${ }^{11}$

It is hard to imagine a more interesting set of great Masters whose art has had a consistent influence on Tadeusz Mysłowski for years. Undoubtedly, this is the result of the Lublin artist's fascination with various types of geometric abstraction, his intuition and artistic sensitivity, but it is also due to Irena Hochman. It was she who opened two Carpenter \& Hochman art galleries in 1984, in cooperation with Laura Carpenter - one in New York and the other one in Dallas - and initiated their activity by showing a unique exhibition of the last American paintings of Piet Mondrian from Harry Holtzman's collection. He was the man who organized and financed the emigration of the great Dutch artist to America, supported him financially until his death and became the sole heir of his work. Tadeusz and Irena became friends with him and were with him until the last moments of his life. Owing to his conversations with Holtzman, but especially thanks to his memories, Mysłowski got the impression that he had "met" Piet Mondrian in person and, in a sense, visited him in his New York studio, and listened to his pertinent comments and wise advice. However, the

11 Szymon Bojko, Krzestotrony Tadeusza Myslowskiego, [in:] Tadeusz Mystowski. KrzestoTrony w hołdzie dla wizjonerów XX wieku, Galeria Fibak, Krakowskie Przedmieście 5, Warszawa XI 2011, fleet printing. 
Polish artist started his adventure with New York from the place where the Dutchman, so highly esteemed by him, ended it. When Mondrian, who had been a fully formed artist for many years, arrived in 1940 to Manhattan, it came as a shock to him (a kind of catharsis), resulting in the creation of, before his death in 1944, three paintings completely different from those he had made before. New York - New York City, Broadway Boogie-Woogie and Victory BoogieWoogie are a kind of tribute paid by the great creator of Neoplasticism to the unique reality of New York. When Tadeusz Mysłowski appeared in the city in May 1970, he was only at the beginning of his own artistic path. However, he also immediately reacted to the city's pulse and the surprisingly logical spatial arrangement of Manhattan which is present in his art to this day. That is why, as I mentioned earlier, Mysłowski gave up the use of colour (in favour of only black-and-white layouts). On the other hand, by integrating his own sense of romanticism, taken from the centuries-old tradition of European civilization, into the network of streets transferred to a plane of white paper, he became an independent artist (individualist), fully aware of his mission. Yet, he has remained interested in a dialogue with the past that inspired him and the contemporary reality of this extraordinary city. He has always been accompanied - if not physically, then certainly spiritually - by Irena, a modest person, who has usually remained in his shadow, but quite frequently demonstrated far more strength than him in many respects. It was thanks to her that the curators of the Museum of Modern Art in New York enthusiastically included a gift from this Polish artist - his portfolio titled Towards Organic Geometry: 163 Selected Photographic Images, 1972-1994 - in their collection of the most important and most valued modern art in the world in 1994. So, Tadeusz has been given enormous support and help from his beloved wife in difficult moments which, after all, were not lacking in their life together.

However, what connects Tadeusz and Irena in a special way is their genuine collector's passion. As for Tadeusz, it already started in art school and was implemented to a limited extent, due to a lack of adequate funds, during his studies at the Academy of Fine Arts in Krakow. Then it continued with increasing momentum after his going abroad, in the United States. As a result, within the collection of over a thousand exhibits now, there is no shortage of Tadeusz's youthful works which, however, constitute only a small part of the carefully selected collection which has been accumulated with passion for decades. It mainly consists of works by 20th-century Polish, European and, naturally, American artists, with an emphasis on representatives of abstract trends (both geometric and hot abstraction), although there are also works by artists who were active at the end of the 19th century, at the turn of the 20th century, in the interwar period, or after 1945. Thus, the collection of Tadeusz and Irena also includes selected compositions by foreign ("textbook") artists, 
such as Amadeo Modigliani, Wassily Kandinsky, Marc Chagall, Henri Matisse, Salvador Dali, Pablo Picasso, Andy Warhol, Victor Vasarely, Piet Mondrian or even the great Renaissance German graphic and painting artist Lucas Cranach the Elder. The creations of Polish artists, both those working in the country and abroad (including Roman Opałka, Feliks Topolski or even Jan Lebenstein), are also represented in an equally impressive manner. These are almost exclusively compositions on paper: prints made using almost all graphic techniques (intaglio, flat and convex printing), drawings, painting sketches and collages, but there are also sculptures (e.g. Alexander Archipenko, Woman Combing her Hair, 1950s (?), plaster, preliminary casting). Thus, we are dealing with a collection that has an outstanding artistic, but also cognitive and educational value, which may be viewed - since recently - as part of the newly established Irena Hochman and Tadeusz Mysłowski Gallery of Temporary Exhibitions in the renovated interiors of the National Museum in Lublin. ${ }^{12}$ Tadeusz and Irena, taking advantage of the celebration of the 700th anniversary of granting civic rights to Lublin in 2017, first organized an exhibition of works from their collection in the then Lublin Museum and then donated part of it to the Museum as a gift, placing the rest - for the time being - on a long-term loan. Since then, the collection has increased by other loaned items, including, among others, a collection of three hundred copies from the best period of the Polish poster school [sic!]. There was also an exhibition of selected works from the collection at the National Museum in Poznań. Both exhibitions were accompanied by very well edited and published catalogues. The Lublin catalogue owes its impressive graphic design, as is traditional at this point, to the merit of Tadeusz Mysłowski, an artist who cares, like not too many other artists, about every detail of the initiatives he participates in. ${ }^{13}$

The ever-growing volume of the collection, as well as conservational considerations (works on paper cannot be on permanent display) will determine that the Irena Hochman's and Tadeusz Mysłowski's Gallery of Temporary Exhibitions at the National Museum in Lublin will change its character from time to time, because the exhibited works will be exchanged. Perhaps, on the occasion of subsequent exhibition openings, at the Museum or one of the

12 First impressions after seeing the new Gallery were described by Anna Hałata, Wokót wystawy. Korespondencje. Artysta wobec kolekcji, „Akcent” 2021, vol. 42, no. 2 (164), pp. 145-153 and Lechosław Lameński, Kolekcja grafiki Ireny Hochman i Tadeusza Mystowskiego w Muzeum Narodowym w Lublinie. Kilka uwag pod wrażeniem niezwykłego daru zza oceanu, Ibid., pp. 139-144.

13 See: Tadeusz Mystowski kolekcja grafiki, [Exhibition catalogue], Zamek Lubelski, MarchMay 2017, exhibition curator Anna Hałata, ed. Muzeum Lubelskie, Lublin 2017 and M jak Mistrzowie. Kolekcja Irena Hochman Tadeusz Mystowski, [Exhibition catalogue], National Museum in Poznań, 22 Nov. 2019 - 23 Feb. 2020, exhibition curators Agnieszka SalamonRadecka and Anna Hałata, ed. Muzeum Narodowe w Poznaniu, Poznań 2019. 
numerous restaurants of the nearby Old Town, we will meet an elderly gentleman of medium height, rather stocky build, with a characteristic head covered by an inseparable hat, curly disordered grey hair sticking out from under a large brim and lively eyes looking out curiously from behind large glasses, accompanied by a petite brunette with a charming smile, dressed with sophisticated elegance by his side. It will surely be Tadeusz Mysłowski and Irena Hochman out of their beloved New York for a while to spend a few happy days in Lublin, which is equally close to their hearts, without interrupting the creative discourse between both worlds/realities which are so important to them.
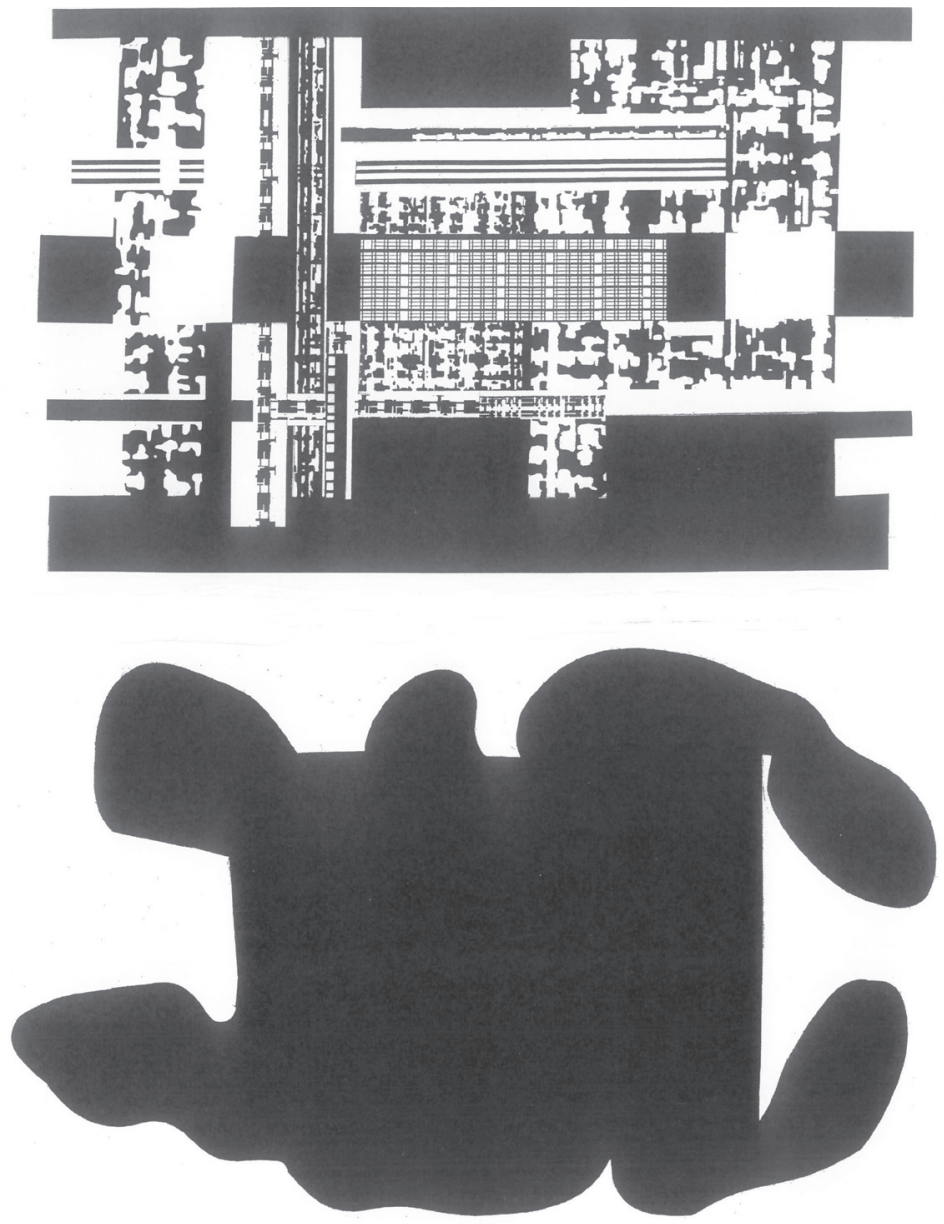

1. Tadeusz Mysłowski, Towards organic geometry, 2021, offset printing, paper; courtesy of the artist 


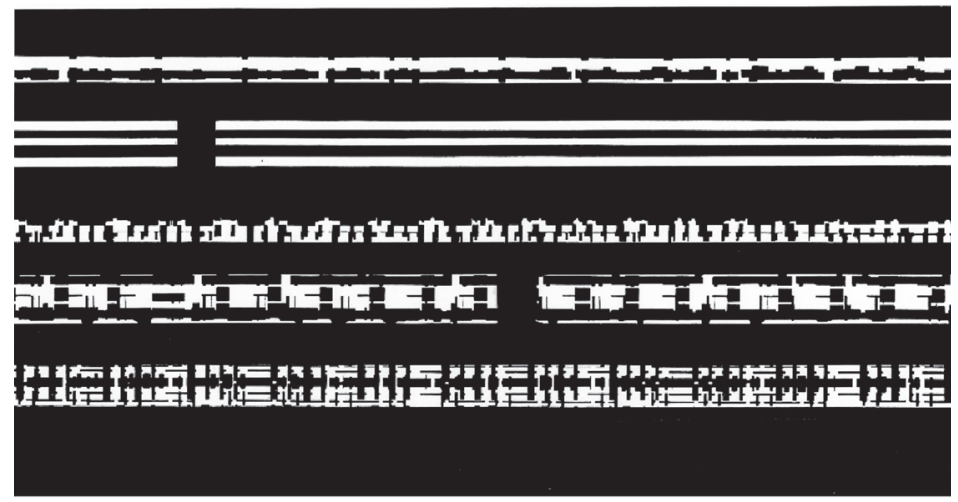

Consider pedestrian traffic in New York: in the street and through the tunnel, above and below the ground, contrasting dark and light, s i l e n ce and ca coph on y. Underground we share a capsule with strangers, often crossing each other's zones of privacy as we speed through the dark. Above ground, the usual boundaries are restored. Compressed together in the subway - theater, we observe the hum a n particles / fragmented views of eyes, lips, ears, hands; a living MONTAGE / and the endless multiplicity of ethnicities.

2. Tadeusz Mysłowski, Avenue of the Americas, 1974, offset printing, paper; courtesy of the artist

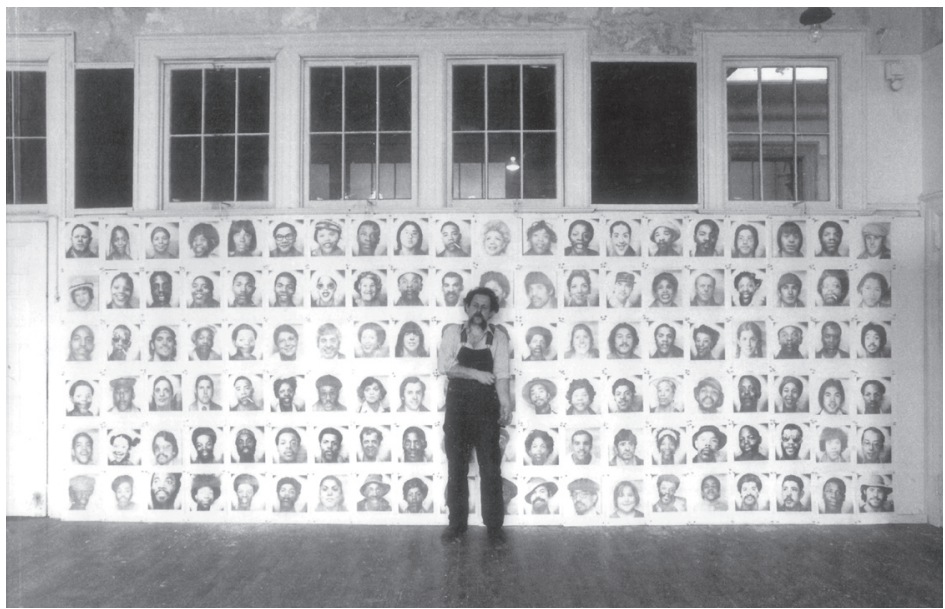

3. Tadeusz Mysłowski, New York faces installation at psi, 1979, photography, photographic paper; courtesy of the artist 


\section{The Museum of Modern Ar:}

December 7, 1994

Dear Ms. Hochman,

It gives me great pleasure to thank you on behalf of the Museum and the Committee on Prints and Illustrated Books for your gift with Tadeusz Myslowski of his 1994 portfolio of 163 offset lithographs, Towards Organic Geometry: 163 Selected Photographic Images, 1972-1994. It was accepted at the Committee's November 8, 1994 acquisitions meeting. Enclosed is the formal receipt for your records.

The members of the Committee were pleased to acquire Myslowski's portfolio of manipulated images derived from the skyscapers along Manhattan's Avenue of the Americas. Scholars and the general public will have the opportunity to view this portfolio in the Abby Aldrich Rockefeller print room. It is a most welcome addition to the Museum's holdings of works by Polish artists and his first work to enter the Collection.

The Trustees join me extending thanks for your thoughtful support of the Museum.

Sincerely yours,

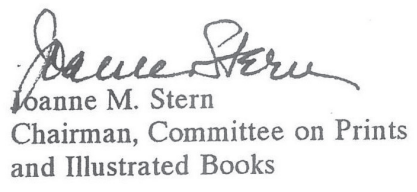

Ms. Irena Hochman

Irena Hochman Fine Art Ltd.

22 East 72nd Street

New York, New York 10021

11 West 53 street, New York, NY. $10019-5498$ Tel: 212-708-9400 Cable: Modernart Telex: 62370 modar?

4. List (of thanks) from The Musem of Modern Art in New York; courtesy of the artist 


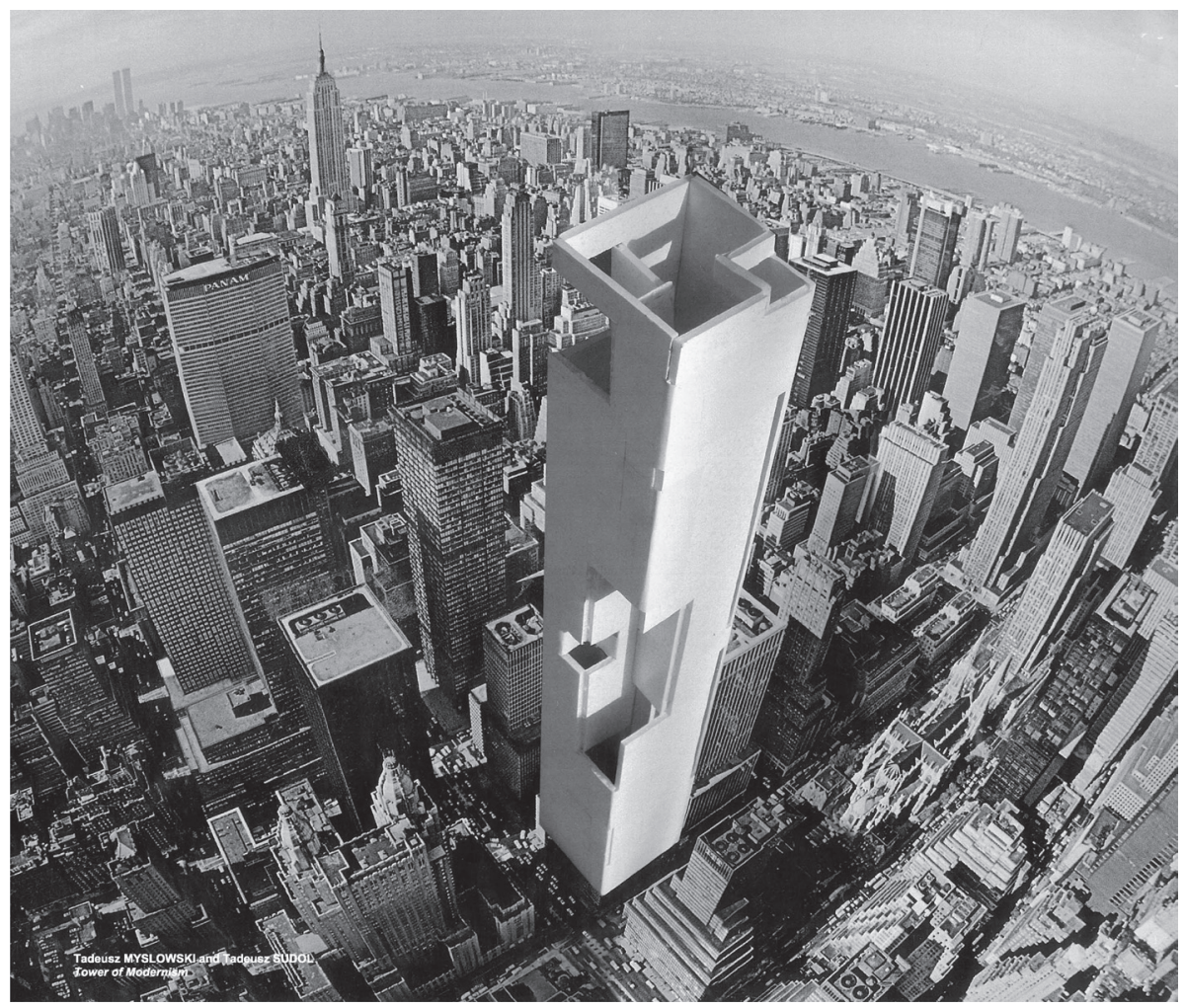

5. Tadeusz Mysłowski, New York Tower of Modernism, the end of the 1990s, photomontage, paper; courtesy of the artist

\section{BIBLIOGRAPHY:}

Bojko Szymon (2011), KrzestoTrony Tadeusza Mystowskiego, [in:] Tadeusz Mystowski. Krzesto -Trony w hołdzie dla wizjonerów XX wieku, Warszawa, Galeria Fibak, Krakowskie Przedmieście 5, fleet printing.

Folga-Januszewska Dorota (2019), Konstruktywizm organiczny Tadeusza Mystowskiego, "Powidoki", vol. 1, no. 2, pp. 24-29.

Hałata Anna (2021), Wokót wystawy. Korespondencje. Artysta wobec kolekcji, "Akcent", vol. 42, no. 2 (164), pp. 145-153.

Lameński Lechosław (2009), Czarno-biaty zapis emocji wedtug Tadeusza Mysłowskiego, "Akcent", vol. 30, no. 3 (117), pp. 167-177. 
Lameński Lechosław (2021), Kolekcja grafiki Ireny Hochman i Tadeusza Mystowskiego w Muzeum Narodowym w Lublinie. Kilka uwag pod wrażeniem niezwyktego daru zza oceanu, "Akcent", vol. 42, no. 2 (164), pp. 139-144.

M jak Mistrzowie. Kolekcja Irena Hochman + Tadeusz Mystowski (2019), [Exhibition catalogue], Muzeum Narodowe w Poznaniu, 22 Nov. 2019 - 23. Feb. 2020, exhibition curators Agnieszka Salamon-Radecka and Anna Hałata, Poznań, ed. Muzeum Narodowe w Poznaniu.

Rybicka Krystyna (2018), Twórczość Tadeusza Mystowskiego a kreacje przestrzeni w sztuce XX wieku, Lublin, ed. Muzeum Lubelskie.

Sztabiński Grzegorz (2004), Działania artystyczne Tadeusza Mystowskiego i ich konteksty, [in:] Idem, Dlaczego geometria? Problemy wspótczesnej sztuki geometrycznej, Łódź, ed. Uniwersytet Łódzki, pp. 158-174.

Tadeusz Mystowski kolekcja grafiki (2017), [Exhibition catalogue], Zamek Lubelski, March-May 2017, exhibition curator Anna Hałata, Lublin, ed. Muzeum Lubelskie.

Then and now New York city fragments Tadeusz Myslowski at the crossroads (2018), a publication accompanying the exhibition Tadeusz Mysłowski studio/pracownia, Lublin, ed. Muzeum Lubelskie.

\section{ARTYSTA I JEGO MIASTO. NOWY JORK W TWÓRCZOŚCI TADEUSZA MYSŁOWSKIEGO (streszczenie)}

Tadeusz Mysłowski (rocznik 1943), urodzony w podlubelskiej wsi Piotrków, absolwent krakowskiej ASP, wyjechał z Polski w 1969 roku. Najpierw do Paryża, a następnie w 1970 roku do Stanów Zjednoczonych. Od tego momentu żyje i tworzy w Nowym Jorku, mieście które stało się dla niego niewyczerpanym źródłem inspiracji. Zafascynowany układem urbanistycznym Manhattanu, niezwykłą siatką jego ulic, zrezygnował z uprawiania tradycyjnego malarstwa na rzecz czarno-białych cykli rysunków, grafik, kolaży, fotomontaży i instalacji, utrzymanych w duchu szczególnie mu bliskiej abstrakcji geometrycznej i konstruktywizmu. Tadeusz Mysłowski (rocznik 1943), urodzony w podlubelskiej wsi Piotrków, absolwent krakowskiej ASP, wyjechał z Polski w 1969 roku. Najpierw do Paryża, a następnie w 1970 roku do Stanów Zjednoczonych. Od tego momentu żyje i tworzy w Nowym Jorku, mieście, które stało się dla niego niewyczerpanym źródłem inspiracji. Zafascynowany układem urbanistycznym Manhattanu, niezwykłą siatką jego ulic, zrezygnował z uprawiania tradycyjnego malarstwa na rzecz czarno-białych cykli rysunków, grafik, kolaży, fotomontaży i instalacji, utrzymanych w duchu szczególnie mu bliskiej abstrakcji geometrycznej i konstruktywizmu. Pojawiają się w nich przetworzone fragmenty zabudowy architektonicznej tego niezwykłego miasta, która prowokuje artystę do nieustającego dyskursu formalnego. Mysłowskiego wspiera niezmiennie jego żona Irena Hochman, historyk sztuki z wykształcenia, właścicielka znaczącej galerii sztuki, ważna postać na amerykańskim rynku sztuki. Tadeusza i Irenę łączy nie tylko płomienna miłość, ale także ogromna pasja kolekcjonerska, która zaowocowała powstaniem interesującego zbioru dzieł artystów polskich, europejskich i amerykańskich, czynnych przede wszystkim w XX wieku. Są to wyłącznie prace na pierze, głównie 
ryciny wykonane we wszelkich możliwych technikach graficznych. W 2017 roku małżonkowie podarowali cześć kolekcji ówczesnemu Muzeum Lubelskiemu na Zamku (ob. Muzeum Narodowe w Lublinie), a część przekazali w depozyt.

Słowa kluczowe: Tadeusz Mysłowski, Irena Hochman, Nowy Jork, fascynacja, miłość, abstrakcja geometryczna, kolekcja

Lechosław Lameński was born in 1949 in Bydgoszcz. An art historian and critic, student and assistant to professors Jacek Woźniakowski and Andrzej Ryszkiewicz, Professor Emeritus at the Institute of Arts Studies of the Catholic University of Lublin. He is primarily interested in Polish art from the mid-19th century to 1939 (especially sculpture and architecture), as well as contemporary Polish artists, mainly from the Lublin milieu. Author of over 360 articles, reviews, introductions to catalogues, encyclopaedia entries, as well as books: Tomasz Oskar Sosnowski, 1810-1886, rzeźbiarz polski w Rzymie (Lublin 1997), Stach z Warty Szukalski i Szczep Rogate Serce (Lublin 2007), Moi artyści, moje galerie. Teksty o sztuce XIX i XX wieku (Lublin 2008), Stanistaw Szukalski. Teksty o sztuce $i$ wypowiedzi polemiczne oraz korespondencja z lat 1924-1938 (Lublin 2013), Zatrzymani w kadrze. Eseje o wspótczesnych artystach lubelskich (Lublin 2016) and the album Szukalski (Warsaw 2018). 